\title{
Genistein-induced apoptosis in MCF-7 cells involves changes in Bak and Bcl-x without evidence of anti-oestrogenic effects
}

\author{
Lai See Po ${ }^{2}$, Thomas T. Wang ${ }^{3}$, Zhen-Yu Chen ${ }^{1}$ and Lai K. Leung ${ }^{1,2} *$ \\ ${ }^{1}$ Food and Nutritional Sciences Programme and ${ }^{2}$ Department of Biochemistry, Faculty of Medicine, \\ The Chinese University of Hong Kong, Shatin, NT, Hong Kong \\ ${ }^{3}$ US Department of Agriculture, Beltsville Human Nutrition Research Center, Phytonutrients Laboratory, \\ Beltsville, MD 20705, USA
}

(Received 23 October 2001 - Revised 7 June 2002 - Accepted 18 June 2002)

\begin{abstract}
South-east Asian women have a lower rate of breast cancer compared with their counterparts in western countries and the difference in soyabean consumption has been claimed to be a major contributing factor. Genistein is the most studied phytochemical in the soyabean. An anti-oestrogenic effect is believed to play a crucial part in its chemopreventive mechanism. In the present study, we expressed oestrogen receptor (OR) in an OR-negative cell line, HepG2, to investigate the pro- and anti-oestrogenic effect of genistein on the OR transcriptional activity. Genistein by itself had an estimated concentration that induced $50 \%$ of the maximum response $\left(\mathrm{EC}_{50}\right)$ of $2.5 \mu \mathrm{M}$ for the binding to OR- $\alpha$. In these experiments, genistein concentration as high as $50 \mu \mathrm{M}$ could not reduce the oestrogen response element-driven luciferase activities initiated by oestradiol. Instead, genistein potentiated the OR transactivational activity while cell death was detected. On the other hand, an increased Bak and a reduced $\mathrm{Bcl}-\mathrm{x}(\mathrm{L})$ was observed at $50 \mu \mathrm{M}$-genistein by Western analysis. The combined effect of these two proteins could be important in the apoptotic process. Since plasma genistein $>50 \mu \mathrm{M}$ has never been documented following consuming of soyabean or soyabean products, the present study does not support the notion that dietary soyabean exerts its chemopreventive effect through antagonizing OR.
\end{abstract}

Genistein: Oestrogen receptor: Anti-oestrogen: Cell death

\begin{abstract}
Breast cancer is one of the most common cancers in women. Women in Asian countries have a lower incidence of breast cancer than those in the West, and the descendants of Asian people who migrated to the USA have lost this favourable characteristic (Ziegler et al. 1993). These observations suggest that environment does play a role in the aetiology of breast cancer. Soyabean consumption has been proposed to be a contributing factor, although this protective effect is not consistent in epidemiological studies (Lamartiniere, 2000). The soyabean isoflavone genistein has been widely studied for its chemopreventive effect in different animal models. Rats treated with genistein in their neonatal period have reduced incidence of dimethylbenz[ $\alpha]$ anthracene-induced breast cancer (Lamartiniere et al. 1995a,b). In cell culture studies, genistein in pharmacological doses has been found to inhibit growth of many cell types including mammary cancer cells (Kuo, 1997).
\end{abstract}

Exposure to oestrogen has been considered a risk factor for breast cancer (Nenci et al. 1988), because it promotes breast-cell proliferation. One of the proposed mechanisms is in the redirection of apoptotic pathways. 17 $\beta$-Oestradiol can reduce the pro-apoptotic Bak level in MCF-7 cells (Leung et al. 1998) and enhances cell survival by increasing Bcl-2 (Wang \& Phang, 1995). The latter is likely to be due to the direct effect of oestrogen receptor (OR) transactivation, because two functional oestrogen response elements (ORE) have been identified at the $b c l-2$ gene promoter region (Perillo et al. 2000).

$\mathrm{OR}$ is an intranuclear binding protein that has a DNAbinding domain and a ligand-binding domain (Pike et al. 2000). When the ligand-binding domain has a ligand bound to it, the OR protein will experience a conformational change and initiate transcription by attaching to an ORE in the gene-specific promoter region. Recently, two subtypes of OR known as $\alpha$ and $\beta$ have been identified,

\footnotetext{
Abbreviations: $\mathrm{EC}_{50}$, concentration that produced $50 \%$ of the maximum response; FBS, fetal bovine serum; $\mathrm{IC}_{50}$, concentration that caused $50 \%$ of inhibition; OR, oestrogen receptor; ORE, oestrogen response element; PS, presenilin.

* Corresponding author: Dr Lai K. Leung, fax + 8522603 7732, laikleung@yahoo.com
} 
and their differences in tissue distribution and ligand affinity have been explored in the treatment of oestrogenrelated diseases (Dechering et al. 2000).

Since most breast-cancer cells are intuitively expressing either OR- $\alpha$ or OR- $\beta$, or both (Suo et al. 2001; Tong et al. 2002), we selected a hepatic cancer cell line HepG2 to examine the specific effect of genistein on OR- $\alpha$. This cell line has been shown to be OR-negative and found to be useful in the evaluation of ligand-receptor interaction by expressing a specific OR isoform in the cells (Barkhem et al. 1997). In the present study, we investigated the correlation of the anti-oestrogenic effect of genistein $v$. apoptosis. Because of its non-discriminatory cytotoxicity to both OR-negative and -positive cell lines (Shao et al. 1998), we hypothesized that an anti-oestrogenic effect was not a determining factor in the apoptosis induced by genistein.

\section{Methods \\ Chemicals}

Genistein was purchased from Sigma Chemical Co. ( $\mathrm{St}$ Louis, MO, USA). All other chemicals were purchased from Sigma if not stated otherwise.

\section{Cell culture}

We obtained the hepatocarcinoma cell line HepG2 from American Type Cell Collection (Rockville, MD, USA). The cells were incubated in Phenol Red-free RPMI 1640 media with (/litre): L-glutamine (Gibco BRL, Rockville, MD, USA) $2 \mu \mathrm{mol}$, penicillin $100000 \mathrm{U}$, streptomycin $100 \mathrm{mg}$, fetal bovine serum (FBS; Gibco BRL) $50 \mathrm{ml}$. The incubator was maintained at $37^{\circ} \mathrm{C}$ in $\mathrm{CO}_{2}$-air $(5: 95, \mathrm{v} / \mathrm{v})$. One week before the beginning of experiments, the cells were switched to the same media with charcoal dextran-treated FBS $(50 \mathrm{ml} / \mathrm{l}$; Hyclone, Logan, UT, USA) instead of FBS. The cells were trypsinized and seeded at a density of $10^{5}$ cells per well in twentyfour-well Costar culture plates (Corning Inc, Corning, NY, USA) $1 \mathrm{~d}$ before treatment started.

\section{Apoptotic death assay}

A cell death detection ELISA kit (Roche Molecular Biochemicals, Mannheim, Germany) was used for this determination. Cells with a density of $5 \times 10^{4}$ per well were plated in twenty-four-well plates (four wells per treatment). After treatment for $48 \mathrm{~h}$, the cells were washed once with PBS and lysed with $0.5 \mathrm{ml}$ lysis buffer included in the kit. DNA fragments in the cell lysates were then quantified by ELISA. An identically treated cell culture plate was used for the cell viability determination by 3-(4,5-dimethylthiazol-2-yl)-2,5-diphenyltetrazolium bromide assay (Hansen et al. 1989). The apoptotic index was then obtained by normalizing the ELISA value with the 3-(4,5-dimethylthiazol-2-yl)-2,5diphenyltetrazolium bromide-absorbance reading.

\section{Oestrogen receptor- $\alpha$ competitive binding assay $v$ transient transfection reporter assay}

Genistein is a competitor with oestrogen for OR-binding in a radiolabelled OR competition assay system (Kuiper et al. 1997) and exhibits biphasic effects on cell proliferations (Wang \& Kurzer, 1997; Breinholt \& Larsen, 1998; Le Bail et al. 1998; Shao et al. 1998). Since the DNA-binding and ligand-binding domains are separate domains, we investigated the anti-oestrogenic effect of genistein by using a transient transfection cell culture model. This system included a sequential events occurred after the activation of $\mathrm{OR}$.

An oestrogen-receptor $(\alpha)$ competition screening kit was obtained from Wako Chemicals (Osaka, Japan) to quantify the competition between genistein and oestradiol for OR- $\alpha$ binding. Genistein was incubated with $10^{-9} \mathrm{M}$-fluorescein-labelled-oestradiol in a ninety-six-well plate coated with recombinant OR- $\alpha$ for $2 \mathrm{~h}$. After flushing the wells with wash buffer, the fluorescence was read at excitation wavelength $480 \mathrm{~nm}$ and emission $530 \mathrm{~nm}$ by a fluorescence plate reader (Fluostar Galaxy; BMG Labtechnologies GmBH, Offenburg, Germany).

The transfection procedures were performed as previously described (Casanova et al. 1999) with slight modification. Human OR- $\alpha$ expression plasmid and ORE-luciferase reporter plasmid were gifts from $\mathrm{Dr}$ Donald McDonnell (Duke University, Durham, NC, USA). HepG2 cells were cultured in twenty-four-well plates and were co-transfected with three different plasmids: ORE-luciferase reporter, OR- $\alpha$ expression and Renilla luciferase control plasmids (Promega Corp., Madison, WI, USA). For each well of cell culture, $0.4 \mu \mathrm{g}$ OR- $\alpha, 0 \cdot 4 \mu \mathrm{g}$ ORE-luciferase and $0 \cdot 1 \mu \mathrm{g}$ Renilla luciferase control plasmids were mixed with $8 \mu$ l lipofectamine (Gibco BRL) at room temperature for $15 \mathrm{~min}$ to form DNA-lipid complexes. The complexes were then mixed in $400 \mu \mathrm{l}$ serum-free RPMI and administered to the cultures for $6 \mathrm{~h}$. When the transfection period was over, the complexes-containing medium were replaced by fresh RPMI with charcoal-dextran treated serum $(50 \mathrm{ml} / \mathrm{l})$. The cells were treated with genistein and $17 \beta$-oestradiol. After a $24 \mathrm{~h}$ treatment, the cells were lysed and assayed for the luciferase activities. The cell lysis buffer and luciferase substrates were provided by a dual-luciferase reporter assay system (Promega). A luminometer (Fluostar Galaxy; BMG Labtechnologies $\mathrm{GmBH}$ ) was used for dualluciferase assay. The reporter firefly luciferase activity was measured by adding luciferase assay reagent II from the kit. The firefly luciferase was then quenched by Stop \& Glo ${ }^{\circledR}$ buffer provided in the kit, followed by the assay of the control Renilla luciferase activity. The firefly luciferase activity was a signal representing OR transactivation activity and the Renilla luciferase reading was employed to normalize the transfection efficiency.

\section{Semi-quantitative reverse transcription-polymerase chain reaction assay}

Total RNA was isolated from cells grown in six-well Costar plates (Corning Inc) in triplicate by a method previously 
described (Wang \& Phang, 1995). RNA (1 $\mu \mathrm{g})$ was used for cDNA synthesis and the final volume was diluted to $100 \mu \mathrm{l}$. A reverse transcription-polymerase chain reaction assay was used to quantify presenilin (PS) 2 mRNA level. Primers of PS2, Bcl-2 and $\beta$-actin, sequences already published (Wang \& Phang, 1995; Wang et al. 1996), were utilized to amplify the target cDNA separately after the first strand reaction. All polymerase chain reaction reactions consisted of $0 \cdot 2 \mathrm{M}$-dNTP, $4 \mu \mathrm{l}$ cDNA, $0 \cdot 2 \mathrm{M}$ each primer, $1 \times$ polymerase chain reaction buffer and $1 \mathrm{U}$ Taq polymerase. The conditions were $94^{\circ} \mathrm{C}$ for $45 \mathrm{~s}, 65^{\circ} \mathrm{C}$ for $45 \mathrm{~s}, 72^{\circ} \mathrm{C}$ for $2 \mathrm{~min}$ and a final extension period of $7 \mathrm{~min}$ at $72^{\circ} \mathrm{C}$. The amplification cycles were twenty-five for PS2 and $\mathrm{Bcl}-2$, and nineteen for $\beta$ actin. The polymerase chain reaction products were separated on agarose $(1.8 \%)$ gel and stained with ethidium bromide. Separate experiments were performed to standardize the amount of RNA and the number of amplification cycles. The validation procedure was based on the linearity of the optical density reading scanned from the gel photographs.

\section{Western analysis}

Treated cells in triplicate were washed once with PBS $(\mathrm{pH}$ 7.4 ) and harvested into a $1.5 \mathrm{ml}$ microtube with $0.5 \mathrm{ml}$ lysis buffer (ml/l PBS: NP40 10, sodium deoxycholate $5 \mathrm{~g}$, SDS $1 \mathrm{~g}$ ). The lysis buffer contained protease inhibitors (/l PBS: phenylmethylsulfonyl fluoride $40 \mathrm{mg}$, aprotinin $0.5 \mathrm{mg}$, leupeptin $0.5 \mathrm{mg}$, EDTA $1.1 \mathrm{mmol}$, pepstatin $0.7 \mathrm{mg}$ ). The harvested cells were then lysed with a Tekmar Sonic Disrupter (Cincinnati, OH, USA) on ice for $30 \mathrm{~s}$. The protein concentration of cell lysate was determined by Dc protein assay (BioRad, Richmond, CA, USA). Lysate protein $(25 \mu \mathrm{g})$ was separated on SDS $(100 \mathrm{ml} / \mathrm{l})-P A G E$ (Novex, San Diego, CA, USA) and transferred to an Immobilon PVDF membrane (Millipore, Bedford, MA, USA). Anti$\mathrm{Bcl}-\mathrm{x}(\mathrm{L})$, anti-Bak, and anti-actin primary and secondary

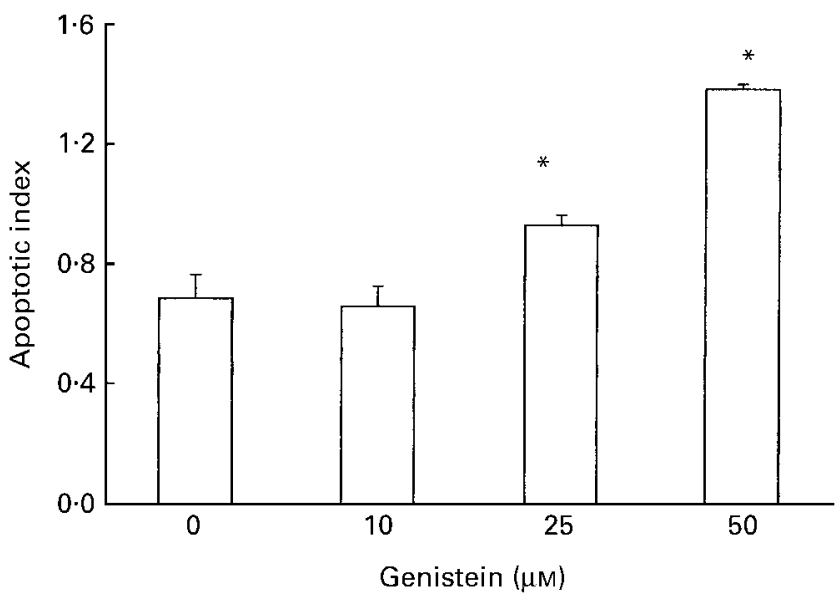

Fig. 1. Cell death induced by genistein: MCF-7 cells were seeded in twenty-four-well culture plates and treated with $0,10,25$ or $50 \mu \mathrm{M}$-genistein for $48 \mathrm{~h}$. A cell death ELISA kit (Roche Molecular Biochemicals, Mannheim, Germany) was used to determine the DNA fragments and the values were normalized by cell viability absorbance readings. For details of procedures, see p. 464 . Values are means for three determinations with standard errors shown by vertical bars. Mean values were significantly different from those of control wells: ${ }^{*} P<0.05$. antibodies conjugated with horseradish peroxidase were obtained from Santa Cruz Biotechnology (Santa Cruz, CA, USA). An ECL detection kit (Amersham, Arlington Heights, IL, USA) provided the chemiluminence substrate for horseradish peroxidase and the targeted protein was visualized by autoradiography for $1-2 \mathrm{~min}$ and the amount was quantified by densitometry.
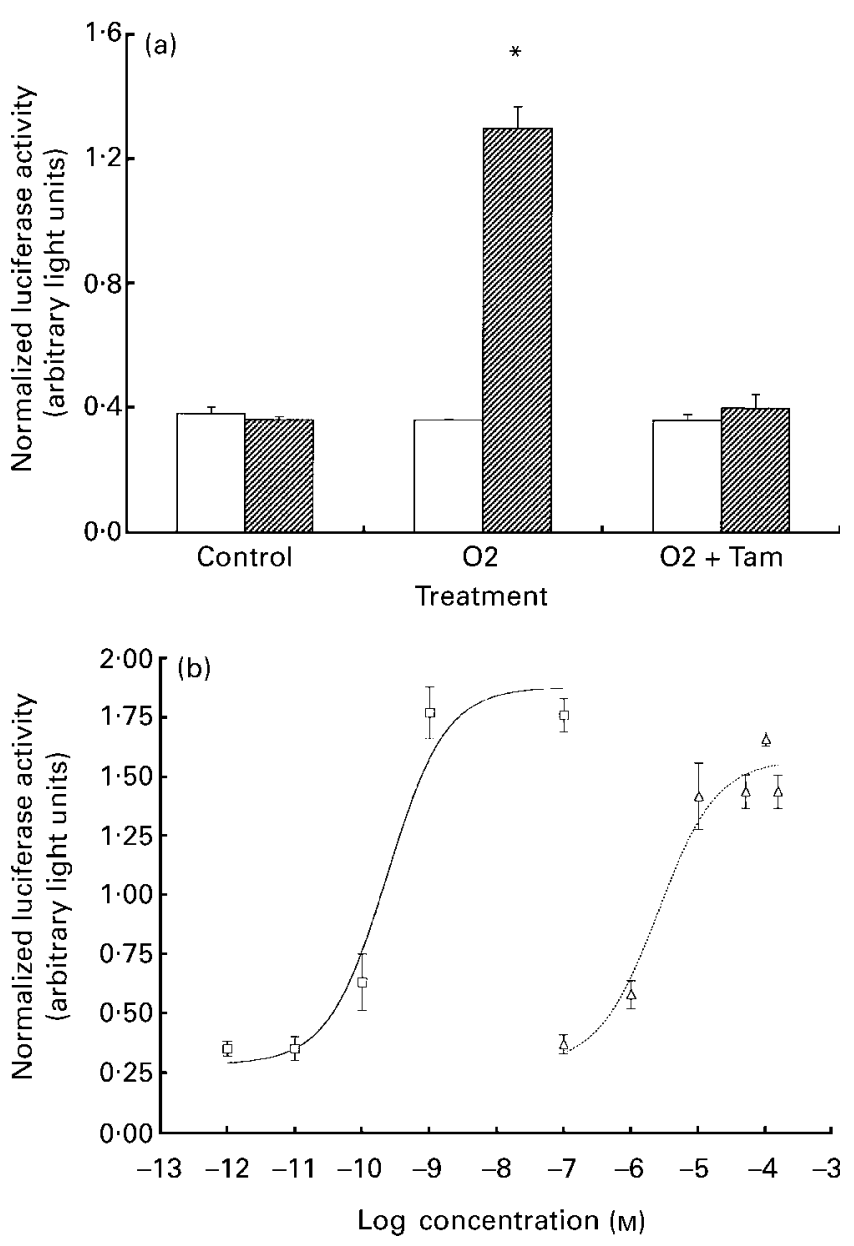

Fig. 2. Genistein-stimulated oestrogen receptor (OR)- $\alpha$ transactivation in HepG2 cells. HepG2 cells were cultured and transfected with oestrogen response element-luciferase, plasmid Renilla luciferase and OR- $\alpha$ expression or vector-only plasmids in twenty-four-well plates. The cells were lysed after $24 \mathrm{~h}$ treatment and the luciferase activities were measured. OR- $\alpha$ transactivation activity was measured as the firefly luciferase activity and normalized with the Renilla luciferase activity as the transfection control. For details of procedures, see p. 464. (a), The transfection of vector-only plasmid was used to show the functional expression of OR- $\alpha$ in HepG2 cells transfected with OR- $\alpha$ expression construct. O2, 17 $\beta$-oestradiol treatment; $\mathrm{O} 2+\mathrm{Tam}$, co-administration of $10^{-9} \mathrm{M}$-oestradiol and $10^{-7} \mathrm{M}$-tamoxifen. $\square$, Vector only; OR plasmid. Values are means for three determinations with standard errors shown by vertical bars. Mean value was significantly different from that of the control wells with no oestradiol treatment: ${ }^{\star} P<0.05$. (b), Various genistein and oestradiol concentrations were administered to the medium to obtain the dose-response relationships of the chemicals. $\square$, Oestradiol; $\Delta$, genistein. Values are means for three determinations with standard errors shown by vertical bars; the points are curve-fitted by a built-in sigmoidal dose-response equation. The concentration that produced $50 \%$ of the maximum response $\left(E_{50}\right)$ of genistein is estimated as $2.5(95 \% \mathrm{Cl} 0.4,16.0) \mu \mathrm{M}$. 


\section{Statistical methods}

A Prism ${ }^{\circledR} 3.0$ software package (GraphPad Software Inc., San Diego, CA, USA) was utilized for statistical analysis. The results, whenever applicable, were analysed by oneway ANOVA followed by Dunnett's multiple comparison test if significant differences $(P<0.05)$ were observed. The OR transactivation luciferase activities and the OR competitive fluorescence readings were curved-fitted by sigmoidal dose-response built-in equations, which automatically calculated the concentration that produced $50 \%$ of the maximum response $\left(\mathrm{EC}_{50}\right)$ and the concentration that caused $50 \%$ of inhibition values $\left(\mathrm{IC}_{50}\right)$. The optical density results of $\mathrm{Bak}$ and $\mathrm{Bcl}-\mathrm{x}(\mathrm{L})$ protein expressions were analysed by one-sample $t$ test followed by Wilcoxon's signed rank test.

\section{Results}

\section{Genistein-induced MCF-7 cell death}

MCF-7 cells were treated with $0,10,25$ and $50 \mu \mathrm{M}-$ genistein for $48 \mathrm{~h}$. The apoptotic indexes at 25 and $50 \mu \mathrm{M}$ were significantly $(P<0.05)$ higher than those of the control cells $(0 \mu \mathrm{M})$ as shown in Fig. 1. This indicated that a significant number of cells undergoing apoptosis in cultures treated with 25 and $50 \mu \mathrm{M}$-genistein.

\section{The oestrogen receptor- $\alpha$ specific transactivation initiated} by genistein

A validation assay was performed to verify the functionality of the OR- $\alpha$ plasmid. HepG2 cells were transfected with ORE-reporter plasmid, Renilla luciferase plasmid, and one of OR-expression plasmid or vector (plasmid

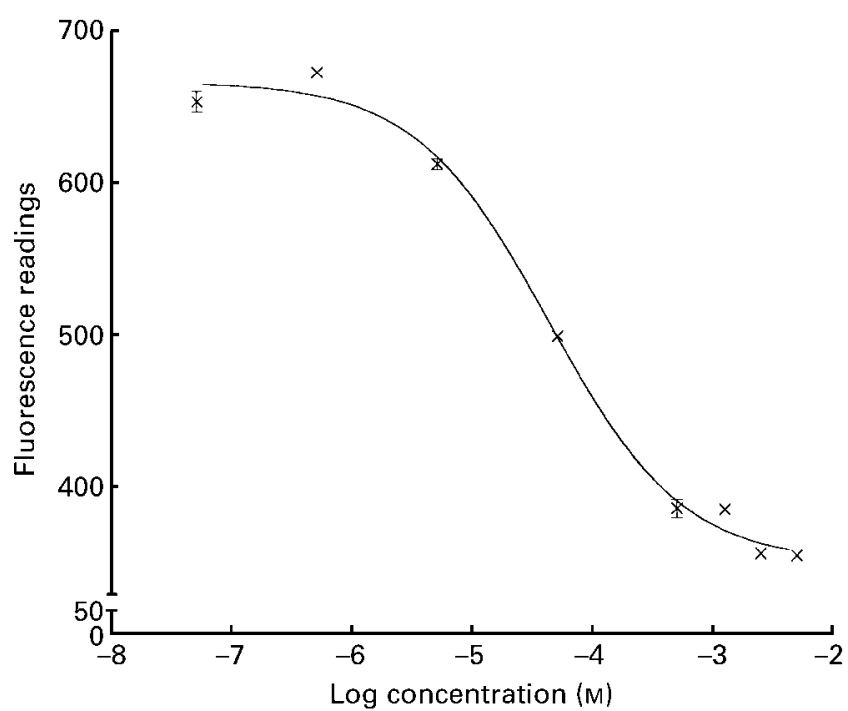

Fig. 3. The competition between genistein and $17 \beta$-oestradiol for binding to oestrogen receptor (OR)- $\alpha$. Various concentrations of genistein were mixed with $10^{-9} \mathrm{M}$-fluorescein-labelled-17 $\beta$ oestradiol, and the mixture was then added to a plate coated with recombinant human OR- $\alpha$. For details of procedures, see p. 464. Values are means for three determinations with standard errors shown by vertical bars. The concentration that caused $50 \%$ of inhibition $\left(\mathrm{IC}_{50}\right)$ is estimated as $48.0(95 \% \mathrm{Cl} 12.0,192.0) \mu \mathrm{M}$. without OR- $\alpha$ insert). Cells transfected with vector only did not respond to oestradiol $\left(10^{-9} \mathrm{M}\right)$ treatment, whereas cells transfected with OR expression plasmid demonstrated an increase in luciferase activity (Fig. 2(a)). The increased luciferase activity could be inhibited by tamoxifen $\left(10^{-7} \mathrm{M}\right)$. The present experiment demonstrated that the OR plasmid was functional. Subsequently, experiments using the same system were carried out to examine genistein's effect on OR- $\alpha$. Genistein displayed a doseresponse oestrogenic effect on HepG2 cells expressing OR- $\alpha$. The normalized luciferase activities indicated that genistein had an $\mathrm{EC}_{50}$ of about $2.5 \mu \mathrm{M}$, whereas the $\mathrm{EC}_{50}$ of $17 \beta$-oestradiol was $0.23 \mathrm{~nm}$ (Fig. 2(b)). The results revealed that the OR- $\alpha$ transactivation by genistein was about 10000 -fold weaker than that of oestradiol.

\section{The competition for oestrogen receptor- $\alpha$ binding}

Having seen the difference in OR- $\alpha$ transactivation between genistein and oestradiol, the receptor binding affinity was also determined. Recombinant human OR- $\alpha$ receptors saturated with $10^{-9} \mathrm{M}$-fluorescein-labelledoestradiol were incubated with various concentrations of genistein. The concentration at which genistein outcompeted half of the fluorescein-labelled oestradiol $\left(\mathrm{IC}_{50}\right)$ was estimated to be $48.0 \mu \mathrm{M}$ (Fig. 3). In addition, we used unlabelled $17 \beta$-oestradiol to correct for the possible interference of the fluorescein conjugate to the receptor, and estimated that the $\mathrm{IC}_{50}$ for the unlabelled oestradiol was $20 \mathrm{~nm}$ (results not shown). These results illustrated that genistein was about 2400-fold weaker than the unlabelled oestradiol for the affinity towards the ligandbinding domain of OR- $\alpha$.

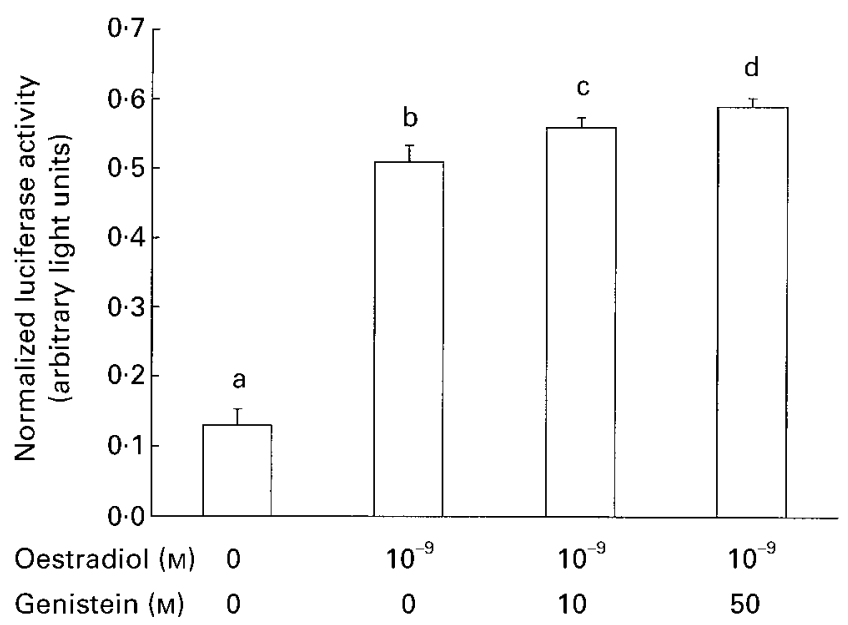

Fig. 4. Effect of genistein on oestradiol-induced oestrogen response (OR)- $\alpha$ transactivation in HepG2 cells. HepG2 cells were cultured and transfected with OR- $\alpha$ oestrogen response element-luciferase and Renilla luciferase plasmids in twenty-four-well plates. Genistein concentrations of 0,10 or $50 \mu \mathrm{M}$ were co-administered with $10^{-9} \mathrm{M}$ $17 \beta$-oestradiol to the medium. The cells were lysed after $24 \mathrm{~h}$ treatment and the luciferase activities were measured. OR- $\alpha$ transactivation activity was measured as the firefly luciferase activity and normalized with the Renilla luciferase activity as the transfection control. For details of procedures, see p. 464. Values are means for three determinations with standard errors shown by vertical bars. Mean values are in the order: $\mathrm{a}<\mathrm{b}<\mathrm{c}<\mathrm{d}(P<0.05$, ANOVA). 
The interaction between genistein and $17 \beta$-oestradiol on the oestrogen response element

In order to investigate the anti-oestrogenicity of genistein, HepG2 cells expressing OR- $\alpha$ were co-treated with $17 \beta$-oestradiol and genistein. Instead of antagonizing the OR- $\alpha$ transactivation induced by oestradiol, 10 and $50 \mu \mathrm{M}$-genistein slightly $(P<0.05)$ increased the transactivation activity (Fig. 4). These results demonstrated that genistein at these two concentrations did not impede the nuclear events initiated by oestradiol.

\section{Presenilin 2 and Bcl-2 mRNA expression}

Because the ORE-driven luciferase activities were increased by genistein in the presence or absence of $17 \beta$-oestradiol, we investigated the transcriptional activities of two oestrogen-responsive genes in MCF-7 cells. Compared with the control $(0 \mu \mathrm{M}$-genistein $)$, the reverse transcription-polymerase chain reaction results indicated that PS-2 and Bcl-2 mRNA expressions were up regulated by genistein at all concentrations tested (Fig. 5). A concentration of genistein of $25 \mu \mathrm{M}$ at which apoptotic induction was observed also induced the expressions. $p s 2$ and $b c l-2$ have been widely accepted as oestrogen-responding genes (Ciocca \& Elledge, 2000). These results agreed to the OR transactivation results presented in Fig. 2.

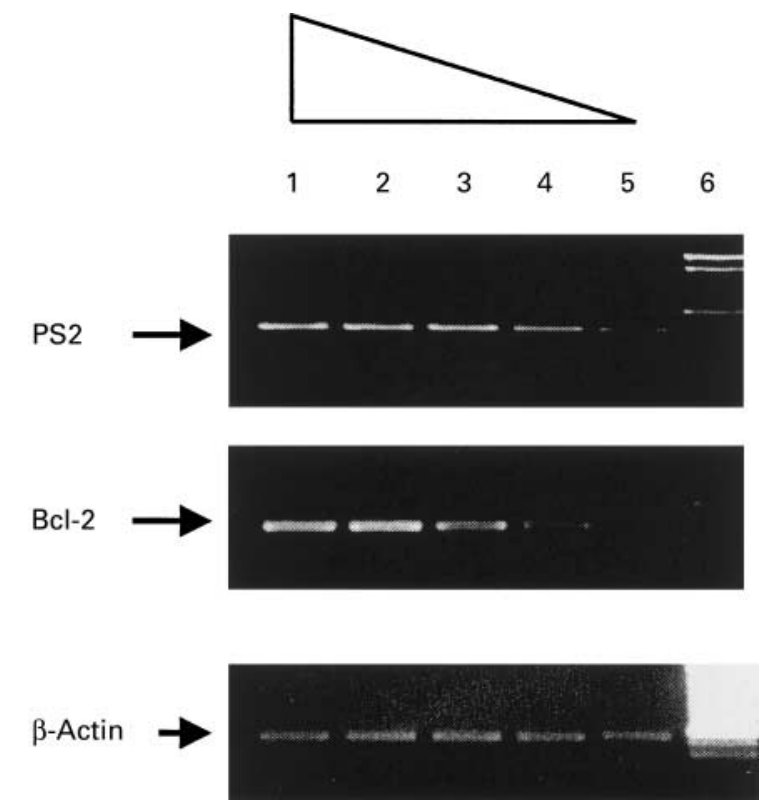

Fig. 5. Effect of genistein on the up-regulation of presenilin (PS) 2 and $\mathrm{Bcl}-2$ mRNA expressions at concentrations leading to cell death. MCF-7 cells were treated with $0,1,10,25$ or $50 \mu \mathrm{M}$-genistein for $48 \mathrm{~h}$. Total RNA were isolated and semi-quantitative reverse transcription-polymerase chain reactions were performed to estimate the expressions of the oestrogen-responsive genes, PS2 and Bcl-2. Lanes 5, 4, 3, 2 and 1 correspond to 0, 1, 10, 25 and $50 \mu \mathrm{M}$-genistein respectively, and lane 6 is a DNA marker. Each set represents one of two separate, independent experiments. For details of procedures, see p. 464

\section{Bak and Bcl-x(L)??? protein expressions affected by genistein}

Since a previous study showed that $\mathrm{Bcl}-2$ and Bak were both increased by genistein (Leung \& Wang, 2000), we examined the role of the other Bcl-2 family members in the death process. Fig. 6 revealed that Bak and Bcl-x(L) protein expressions were differentially regulated by genistein at the concentrations which cell death was observed. Bak expression in cultures treated with $50 \mu \mathrm{M}$-genistein was higher $(P<0.05)$ than the control $(0 \mu \mathrm{M}$-genistein $)$, whereas $\mathrm{Bcl}-\mathrm{x}(\mathrm{L})$ expression was decreased $(P<0.05)$ by 25 and $50 \mu \mathrm{M}$-genistein.

\section{Discussion}

In the present study, we demonstrated that genistein potentiated OR transactivation with oestradiol administration, and correlation of OR antagonism and MCF-7

(a)

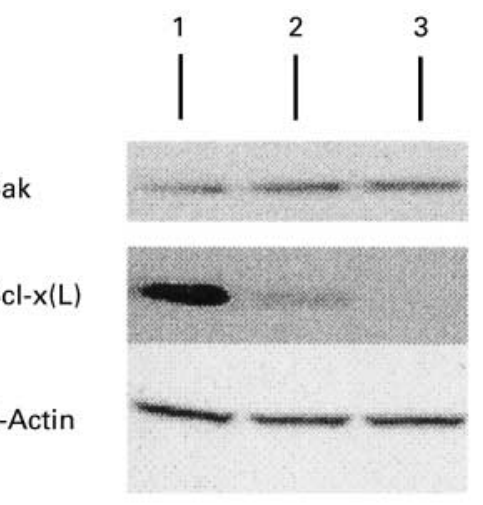

(b)

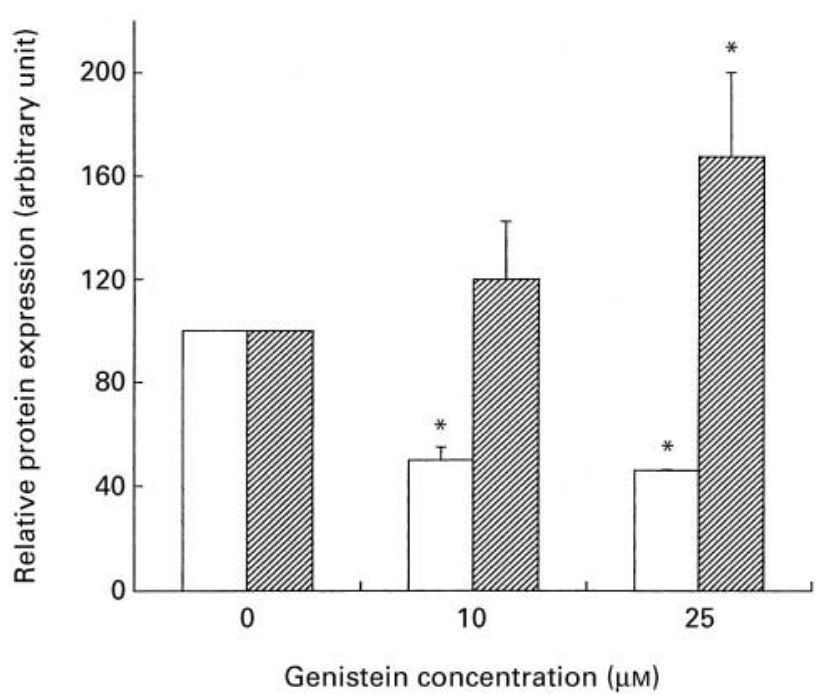

Fig. 6. Effect of genistein on Bak and $\mathrm{Bcl}-\mathrm{x}(\mathrm{L})$ protein expressions (a), Western analysis of MCF-7 cells treated with 0,25 or $50 \mu \mathrm{M}$ genistein (lanes 1, 2 and 3 respectively). The blot represents one of three separate, independent experiments; (b), optical densities of Bak and $\mathrm{Bcl}-\mathrm{x}(\mathrm{L})$ proteins obtained in (a). $\beta$-Actin-normalized values are expressed as \% control and are shown as mean values for three determinations with standard errors shown by vertical bars. $\square$, Bcl-x(L); 四, Bak. For details of procedures, see p. 464. Mean values were significantly different from those of the control wells: ${ }^{\star} P<0.05$. 
cell death was not observed. It appeared the replacement of oestradiol by genistein as the ligand of OR did not deter the transactivation. When administered alone, genistein could increase PS2 and Bcl-2 mRNA expressions at the concentrations leading to cell death. These results suggested that genistein was a potentiator instead of an antagonist in the OR-initiated nuclear event at the death concentrations. On the other hand, Bak protein expression was up regulated while $\mathrm{Bcl}-\mathrm{x}(\mathrm{L})$ was down-regulated by genistein at concentrations at which death was observed. These differential protein expressions favoured programmed cell death.

Many studies have shown that genistein is an agonist of OR, both in an animal model (Makela et al. 1995) or in cell culture models (Wang et al. 1996; Fioravanti et al. 1998; Miodini et al. 1999). Others studies have claimed that genistein is an antagonist of OR. Kuiper et al. (1997) have expressed rat OR- $\alpha$ and $-\beta$ and found that genistein competes with $17 \beta$-oestradiol for the ligand-binding domain of OR- $\alpha$ and $-\beta$. These results, and those of the present study, suggest that the receptor-binding replacement of oestrogen by genistein could not stop the initiation of ORE transactivating events. OR- $\alpha$ plays a crucial role in growth and differentiation of mammary gland, but its role in carcinogenesis has not been desirable. By contrast, the role of OR- $\beta$ in breast cancer has yet to be defined. Premalignant breast tissue expresses more OR- $\alpha$ than normal breast tissue (Allred \& Mohsin, 2000). The OR- $\alpha$ gene, however, is mostly lost in more advanced types of breast tumour (Sheng et al. 1996).

Recent studies have shown that genistein displays a proliferative effect at low concentrations $(\mu \mathrm{M})$ (Wang \& Kurzer, 1997; Breinholt \& Larsen, 1998; Le Bail et al. 1998; Shao et al. 1998) and a cytotoxic effect at higher concentrations (Peterson \& Barnes, 1991; So et al. 1997) in MCF-7 cells. However, the mechanism of cell death may not go through OR. A Bcl-2-independent pathway, for example the c-jun $\mathrm{N}$-terminus kinase-mediated stress pathway, may be responsible for the apoptotic response of MCF-7 cells treated with 25 and $50 \mu \mathrm{M}$-genistein (Leung \& Wang, 2000). That study that suggested that multiple pathways were involved in the action of genistein. At low concentrations, genistein reinforced ORE responses, which in turn might encourage proliferation in hormone-sensitive cells. Nonetheless, genistein could activate OR-independent pathways in the mediation of cell death as the dosage progressed.

The oestradiol and OR interaction can be multifaceted. There are at least four known oestradiol-initiated signalling pathways as reviewed by Hall et al. (2001). Two of them require the presence of ORE and others are ORE-independent. The transcriptional binding sites, AP1, (Paech et al. 1997), Sp-1 (Batistuzzo de Medeiros et al. 1997), raloxifene response element (Yang et al. 1996) and genes containing the antioxidant response element (Montano \& Katzenellenbogen, 1997) are all responsive to oestrogen administration. In the present study, we examined the classical ORE dependent pathways and found that genistein was not an effective antagonist of oestradiol. However, we could not rule out the possibility that genistein antagonized the ORE-independent signalling pathways. An et al. (2001) have demonstrated that genistein may selectively generate an activation function-2 surface of OR- $\beta$ that recruits co-regulators for the repression and activation of transcription. Since we did not examine the OR$\beta$-mediated response in the present study, the effect of genistein on the downstream pathways of OR- $\beta$ (either ORE dependent or independent) remain unknown. Considering the influences on the other promoters, it is still possible that genistein can be a pro- or anti-oestrogen, modulating transcription processes other than those dictated by ORE or OR- $\alpha$.

The dietary relevance of the genistein dosages is not clearly established. Plasma concentrations of genistein ranging from $<1 \mu \mathrm{M}$ (Arai et al. 2000) to $23 \mu \mathrm{M}$ (Barnes, 1995) have been reported. Nevertheless, it appears that the classical anti-oestrogenic effect mediated by OR- $\alpha$ to be is unlikely a determining factor in cell death induced by genistein.

\section{Acknowledgements}

This work was supported by the Chinese University of Hong Kong Direct Grant for Research code 2040789. The authors would also like to thank Ms Susan Maness of C.I.I.T. (Research Triangle Park, NC, USA) for her valuable help, and Dr Donald McDonnell of Duke University (Durham, NC, USA) for his generosity of providing the OR expression and ORE-luciferase plasmids.

\section{References}

Allred D \& Mohsin SK (2000) Biological features of human premalignant breast disease. In Diseases of the Breast, pp. 355-366 [JR Harris, editor]. Philadelphia, PA: Lippincott Williams \& Wilkins.

An J, Tzagarakis-Foster C, Scharschmidt TC, Lomri N \& Leitman DC (2001) Estrogen receptor $\beta$-selective transcriptional activity and recruitment of coregulators by phytoestrogens. Journal of Biological Chemistry 276, 17808-17814.

Arai Y, Uehara M, Sato Y, Kimira M, Eboshida A, Adlercreutz H \& Watanabe S (2000) Comparison of isoflavones among dietary intake plasma concentration and urinary excretion for accurate estimation of phytoestrogen intake. Journal of Epidemiology 10, 127-135.

Barkhem T, Andersson-Ross C, Hoglund M \& Nilsson S (1997) Characterization of the estrogenicity of tamoxifen and raloxifene in HepG2 cells: regulation of gene expression from an ERE controlled reporter vector versus regulation of the endogenous SHBG and presenilin 2 genes. Journal of Steroid Biochemistry and Molecular Biology 62, 53-64.

Barnes S (1995) Effect of genistein on in vitro and in vivo models of cancer. Journal of Nutrition 125, 777S-783S.

Batistuzzo de Medeiros SR, Krey G, Hihi AK \& Wahli W (1997) Functional interactions between the estrogen receptor and the transcription activator $\mathrm{Sp} 1$ regulate the estrogen-dependent transcriptional activity of the vitellogenin $\mathrm{A} 1$ io promoter. Journal of Biological Chemistry 272, 18250-18260.

Breinholt V \& Larsen JC (1998) Detection of weak estrogenic flavonoids using a recombinant yeast strain and a modified MCF-7 cell proliferation assay. Chemical Research in Toxicology 11, 622-629.

Casanova M, You L, Gaido KW, Archibeque-Engle S, Janszen DN \& Heck H d'A (1999) Developmental effects of dietary phytoestrogens in Sprague-Dawley rats and interactions of 
genistein and daidzein with rat estrogen receptors $\alpha$ and $\beta$ in vitro. Toxicological Sciences 51, 236-244.

Ciocca DR \& Elledge R (2000) Molecular markers for predicting response to tamoxifen in breast cancer patients. Endocrine 13, $1-10$.

Dechering K, Boersma C \& Mosselman S (2000) Estrogen receptors alpha and beta: two receptors of a kind? Current Medicinal Chemistry 7, 561-576.

Fioravanti L, Cappelletti V, Miodini R, Ronchi E, Brivio M \& Di Fronzo G (1998) Genistein in the control of breast cancer cell growth: insights into the mechanism of action in vitro. Cancer Letters 130, 143-152.

Hall JM, Couse JF \& Korach KS (2001) The multifaceted mechanisms of estradiol and estrogen receptor signalling. Journal of Biological Chemistry 276, 36869-36872.

Hansen MN, Nielsen EE \& Berg K (1989) Re-examination and further development of a precise and rapid dye method for measuring cell growth/cell kill. Journal of Immunological Methods 119, 203-210.

Kuiper GJM, Carlsson B, Grandien K, Enmark E, Haggblad J \& Gustafsson J-K (1997) Comparison of the ligand binding specificity and transcript tissue distribution of estrogen receptors $\alpha$ and $\beta$. Endocrinology 138, 863-870.

Kuo S-M (1997) Dietary flavonoid and cancer prevention: evidence and potential mechanism. Critical Reviews in Oncogenesis 8, 47-69.

Lamartiniere CA (2000) Protection against breast cancer with genistein: a component of soy. American Journal of Clinical Nutrition 71, Suppl., 1705S-1707S.

Lamartiniere CA, Moore JB, Brown NM, Thompson R, Hardin MJ \& Barnes S (1995a) Genistein suppresses mammary cancer in rats. Carcinogenesis 16, 2833-2840.

Lamartiniere CA, Moore J, Holland MB \& Barnes S (1995b) Neonatal genistein chemoprevents mammary carcinogenesis. Proceedings of the Society for Experimental Biology and Medicine 208, 120-123.

Le Bail JC, Varnat F, Nicolas JC \& Habrioux G (1998) Estrogenic and anti-proliferative activities on MCF-7 human breast cancer cells by flavonoids. Cancer Letters 130, 209-216.

Leung LK, Lin D \& Wang TTY (1998) Regulation of death promoter Bak expression by cell density and $17 \beta$-estradiol in MCF-7 cells. Cancer Letters 124, 1-6.

Leung LK \& Wang TT (2000) Bcl-2 is not reduced in the death of MCF-7 cells at low genistein concentration. Journal of Nutrition 130, 2922-2926.

Makela S, Santti R, Salo L \& McLachlan JA (1995) Phytoestrogens are partial estrogen agonists in the adult male mouse. Environmental Health Perspectives 103, Suppl., $123-127$.

Miodini P, Fioravanti L, Di Fronzo G \& Cappelletti V (1999) The two phyto-oestrogens genistein and quercetin exert different effects on oestrogen receptor function. British Journal of Cancer 80, 1150-1155.

Montano MM \& Katzenellenbogen BS (1997) The quinone reductase gene: a unique estrogen receptor-regulated gene that is activated by antiestrogens. Proceedings of National Academy of Sciences USA 94, 2581-2586.
Nenci I, Marchetti E \& Querzoli P (1988) Commentary on human mammary pre-neoplasia. The estrogen receptor-promotion hypothesis. Journal of Steroid Biochemistry B 105-106.

Paech K, Webb P, Kuiper GG, Nilsson S, Gustafsson J, Kushner PJ \& Scanlan TS (1997) Differential ligand activation of estrogen receptors ER alpha and ER beta at AP1 sites. Science 277, 1508-1510.

Perillo B, Sasso A, Abbondanza C \& Palumbo G (2000) $17 \beta$-Estradiol inhibits apoptosis in MCF-7 cells inducing bcl-2 expression via two estrogen-responsive elements present in the coding sequence. Molecular Cell Biology 20, 2890-2901.

Peterson G \& Barnes S (1991) Genistein inhibition of the growth of human breast cancer cells: independence from estrogen receptors and the multi-drug resistance gene. Biochemical and Biophysical Research Communications 179, 661-667.

Pike AC, Brzozowski AM \& Hubbard RE (2000) A structural biologist's view of the oestrogen receptor. Journal of Steroid Biochemistry and Molecular Biology 74, 261-268.

Shao Z-M, Alpaugh ML, Fontana JA \& Barsky SH (1998) Genistein inhibits proliferation similarly in estrogen receptorpositive and negative human breast carcinoma cell lines characterized by $\mathrm{p} 21 \mathrm{WAF} 1 / \mathrm{CIP} 1$ induction G2/M arrest and apoptosis. Journal of Cell Biochemistry 69, 44-54.

Sheng ZM, Marchetti A, Buttitta F, Champeme MH, Campani D, Bistocchi M, Lidereau R \& Callahan R (1996) Multiple regions of chromosome $6 \mathrm{q}$ affected by loss of heterozygocity in primary human breast carcinomas. British Journal of Cancer 73, 144-147.

So FV, Guthrie N, Chambers AF \& Carroll KK (1997) Inhibition of proliferation of estrogen receptor-positive MCF-7 human breast cancer cells by flavonoids in the presence and absence of excess estrogen. Cancer Letters 112, 127-133.

Suo Z, Berner HS, Risberg B, Karlsson MG \& Nesland JM (2001) Estrogen receptor-alpha and C-ERBB-4 expression in breast carcinomas. Virchows Archiv 439, 62-69.

Tong D, Schuster E, Seifert M, Czerwenka K, Leodolter S \& Zeillinger R (2002) Expression of estrogen receptor beta isoforms in human breast cancer tissues and cell lines. Breast Cancer Research and Treatment 71, 249-255.

Wang C \& Kurzer MS (1997) Phytoestrogen concentration determines effects on DNA synthesis in human breast cancer cells. Nutrition and Cancer 28, 236-247.

Wang TT, Sathyamoorthy N \& Phang JM (1996) Molecular effects of genistein on estrogen receptor mediated pathways. Carcinogenesis 17, 271-275.

Wang TTY \& Phang JM (1995) Effects of estrogen on apoptotic pathways in human breast cancer cell line MCF-7. Cancer Research 55, 3902-3907.

Yang NN, Venugopalan M, Hardikar S \& Glasebrook A (1996) Identification of an estrogen response element activated by metabolites of 17beta-estradiol and raloxifene. Science 273, $1222-1225$.

Ziegler RG, Hoover RN, Pike MC, Hidesheim AA, Nomura AM, West DDW, Wu-Williams AAH, Kolonel LN, Horn-Ross PL \& Rosenthal JF (1993) Migration patterns and breast cancer risk in Asian-American women. Journal of National Cancer Institute 85, 1819-1827. 